\title{
In Memoriam: Allan John Hudson
}

by Fred Robinson, Regina

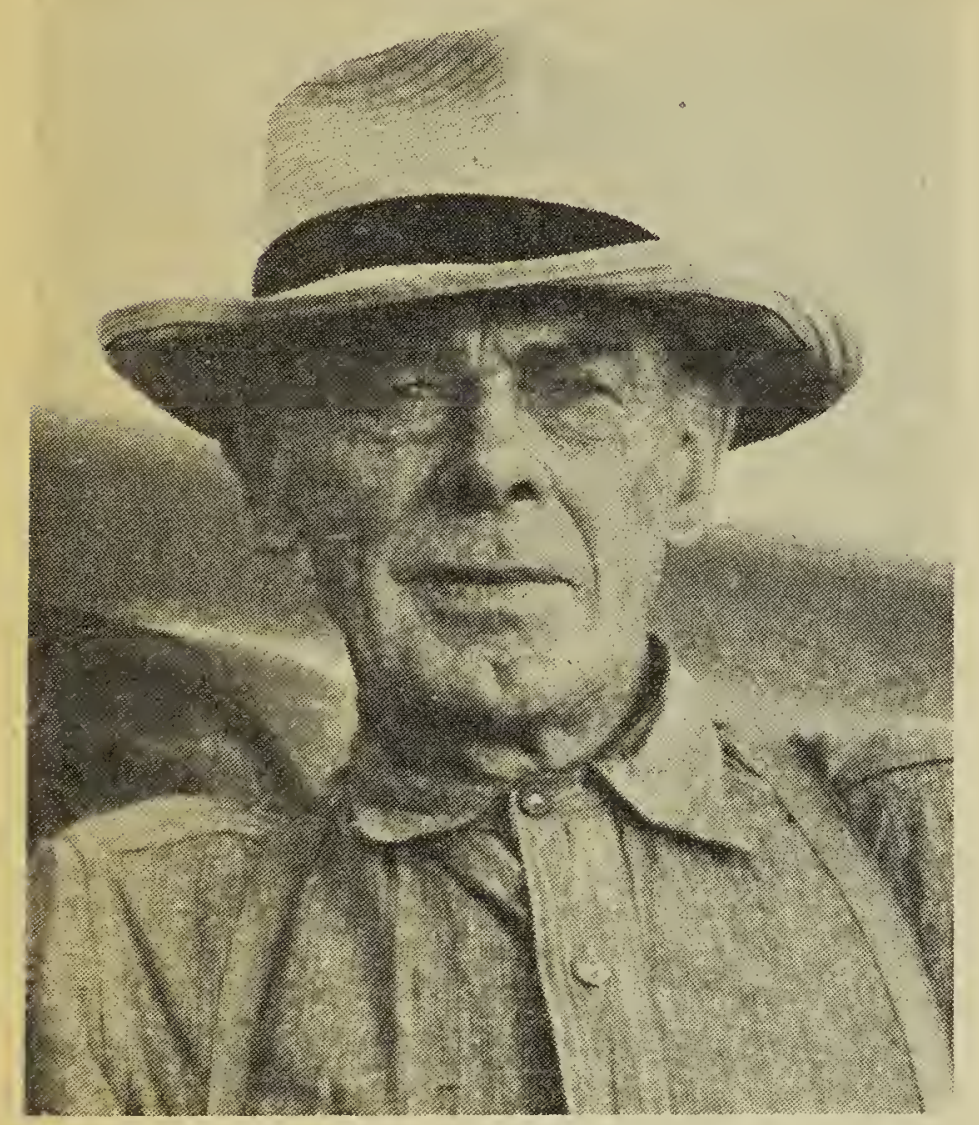

ALLAN HUDSON

Photo by F. G. Bard

On September 29, 1959, death claimed Allan Jorn Hudson of Mortlach, well-known amateur archae- ologist, who has on many occasions made splendid contributions to the pages of this publication. Mr. Hudson was 70 years old and had spent his life since coming from England at age 16 in the Mortlach area. Originally he came from England in search of better health but he decided to stay in Canada and seek ris fortune homesteading. He became a keen student of the origin of man. This interest induced him to study archaeology and on that subject he published many articles, a number of which appeared in these pages.

Perhaps Mr. Hudson's most notable contribution to archaeology was made when the Mortlack: "Besant Site" was discovered in 1948. Later, in 1954, this site was thoroughly excavated by Boyd Wettlaufer, and one of the most eager helpers in the project was Mr. Hudson. Although an amateur he truly loved to work as a professional, which he did with the finest enthusiasm.

Mr. Hudson's contributions to this publication will be missed and his friendship to all members of our society will be mighty hard to replace.

\section{More Painted Turtles}

I enjoyed the article on the Painted Turtle in Saskatchewan by Charles D. Bird in the September issue of tree Blue Jay very much as I am interested in that sort of thing, although I had never seen one of these little creatures until I read the article. However, last Friday afternoon, Sept. 11, an adult Painted Turtle made its way from somewhere into the barnyard at the Experimental Farm here at Indian Head and one of our employees brought it up to my office as he was afraid it might get killed or injured. Needless to say, I was delighted to see it and, as we are farmers soutr. of Indian Head, I took it home with me and put it into our dam, where I hope it will be safe. I presume this was an adult turtle as the shell was $71 / 2$ inches in length. It was not injured in any way, and was presumably in good condition because the colours on the shell underneath were very bright, also on its legs and the rest of its body. We are approximately 14 miles due soutr. of the Qu'Appelle Valley here, so that is quite a hike for one of those little creatures, if it did come from the valley.-Mrs. L. E. Kirchner, Indian Head, Sask.

We saw a Painted Turtle on Renfret Creek, a tributary of the Souris River, this summer while golfing. This we examined closely and noticed its resemblance to a Tortoise that we had for a pet some years ago. The shell size is approximately seven inches by five inches. After further discussion, we found that $\mathrm{Mr}$. R. Williamson of Weyburn saw a great number of these turtles sunning themselves on a river bank some years ago.-Keith D. Baker, Weyburn, Sask. 